\title{
THE EFFECTS OF WOOD CHIPS AND SLASH USAGE ON SKID TRAIL SHEET EROSION CAUSED BY LOG SKIDDING USING A FARM TRACTOR
}

\author{
UČINCI UPORABE DRVNE SJEČKE I ŠUMSKIH DRVNIH OSTATAKA \\ NA POVRŠINSKU EROZIJU TRAKTORSKIH VLAKA UZROKOVANU \\ PRIVLAČENJEM OBLOG DRVA POLJOPRIVREDNIM TRAKTOROM
}

YILMAZ TURK $^{1 *}$, MURAT YILDIZ²

\begin{abstract}
SUMIMARY
This study investigated the sheet erosion that occurs as a result of log skidding operations using a farm tractor on skid trails and the use of wood chips and slash in order to minimize the soil loss. A total of four blocks (sample fields) were formed in four designated skid trails in the study area and three runoff plots were established in each block. One of the runoff plots was left empty as a control (CNT). Wood chips (C) was placed in the second plot and logging residue slash (S) in the third. A total of 108 water samples were taken from the test sites, 36 from each of the control, wood chips and slash plots. The water samples were brought to the laboratory and placed in an heating oven. After the runoff water was evaporated, the remaining sediment was weighed on a sensitive scale. The specified value was calculated according to the total amount of runoff accumulated in the storage tank and the total suspended sediment it carried. As a result, the amount of the average runoff in the CNT was determined as $6.32 \mathrm{~mm} / \mathrm{m}^{2}$, in the C as $6.13 \mathrm{~mm} / \mathrm{m}^{2}$ and in the $S$ as $6.03 \mathrm{~mm} / \mathrm{m}^{2}$. The average amount of suspended sediment transported in the CNT was found as $2.58 \mathrm{~g} \mathrm{~m}^{-2}$, in the $\mathrm{C}$ as $1.61 \mathrm{~g} \mathrm{~m}^{-2}$ and in the $\mathrm{S}$ as $2.13 \mathrm{~g} \mathrm{~m}^{-2}$. Therefore, the amount of soil loss in the control plots was about 1.2 times higher than in the slash plots and 1.6 times higher than in the wood chips plots. In this study, variance analysis results showed a statistically significant difference between the suspended sediment quantities carried from the plots $(p<0.05)$. This study demonstrated that logging residues can be used to reduce the sheet erosion that occurs in skid trails after log extraction.
\end{abstract}

KEY WORDS: skid trails, log skidding, sheet erosion, logging residues, rehabilitation, Turkey

\section{INTRODUCTION}

\section{UVOD}

Log extraction is one of the important steps in the production of wood-based forest products. The extraction process includes various implements and methods, depending on technical, economic and environmental perspectives. Farm tractors are used for a variety of forest harvesting tasks, including felling, processing, extraction, and transportation (Spinelli et al., 2015). Skidding with farm tractors is a very common extraction method which has many advantages, such as low investment costs, for small-scale forests (Magagnotti and Spinelli, 2011). 
Protecting forests and at the same time utilizing them can lead to difficulties when it comes to decision making in forestry operations. As a result of the removal of logs, damage occurs at different rates for the soil, the remaining stand, and the products produced (Bayoğlu, 1972; Gürtan, 1975; Acar, 1994). The stand soil is damaged in different proportions, especially when logs are removed from sloping areas. Continual log skidding over the same places causes both the dead and living soil cover to be carried away and minerals to be leached out of the soil. When the skidding process continues over the same place, mineral soil is carried away and erosion-susceptible channels are formed which cause serious problems during heavy rainfalls. After heavy winter conditions and spring rains, the erosive power of the surface runoff can create damage on the skid trails (Gürtan, 1975; Ylldırım 1989).

The environmental damage that occurs to the soil as a result of the application of log extraction skidding techniques includes the decline in the physical properties of the soil (Arocena, 2000; Makineci et al., 2007; Ozturk, 2016), reduction of plant growth and changes in species diversity, decrease of soil organic matter, humification and mineralization due to effects on the living conditions and activities of soil organisms, and nitrogen losses through denitrification (Marshall, 2000; Buckley et al., 2003; Godefroid and Koedam, 2004). Skidding also causes trauma and injury to saplings and breaks trees (Ünver and Acar, 2009; Turk and Gumus, 2015; Cudzik, 2017). Moreover, skidding operations significantly change the quality and temperature of river waters and affect the nutrient cycle in riparian ecosystems. This is primarily due to the sediment flow into drainage systems caused by skid trails (Messina et al., 1997).

Skid trails are 2.5-3.5 m-wide transport facilities that are planned before the production of the logs by first clearing the trees from the trail to make it $1 \mathrm{~m}$ wider than the production vehicles. These trails are planned for different slopes (0-40\% from top to bottom) according to the specifications of the skidders used in the operation. The study area was limited to areas of agricultural tractor skid trails having slopes of 0-33\% (Turk and Gumus, 2015).

In order to minimize negative environmental effects in the skid trails, four methods are applied. The first and the most important is the appropriate planning of the skid trail network. There are four types of skid trail networks: random, branch, parallel and direct. In this case, random skid trails result in about $25 \%$ more ground disturbance than designated skid trails. Two common patterns are the branching and the parallel skid trails (Garland, 1997). Direct patterns were observed to be the best in terms of the forested areas and density per hectare; however, little difference was found between the branch and the parallel patterns (Gumus and Turk, 2016). The second application for reducing negative effects is the method of laying logging residues on skid trails. The kinetic energy of rain along with landfilling, aggregating and erosion are reduced by this method and sheet erosion can be prevented (Balc1, 1978). In the third application, soil compaction in post-production skid trails is reduced by turning over the trail soil with the help of a ripper. In addition, in places where the skid trail is too long, a natural bump is built on top of the trails to limit soil erosion. The fourth application for the stabilization of the skid trail surface is the planting method. Biological (cultural) measures applied for this purpose include spraying a seed-filled emulsion, dry sowing and the laying of grass lawn sod.

This study investigated the sheet erosion and soil loss caused by industrial log skidding operations using farm tractors on skid trails and assessed the use of wood chips and slash to minimize this loss.

\section{MATERIALS AND METHODS MATERIJALI I METODE}

\section{Study area - Područje istraživanja}

The study area is located in the Asar district ( $40^{\circ} 39^{\prime}$ ' $52^{\text {“ }}-40$ ${ }^{\circ} 45^{\prime} 8^{\prime \prime} \mathrm{N}, 31^{\circ} 17^{\prime} 488^{\prime \prime}-31^{\circ} 27^{\circ} 4$ ” E) in the Western Black Sea province of Duzce, Turkey, where farm tractor usage is

Table 1. General information related to the study area

Tablica 1. Opće informacije o području istraživanja

\begin{tabular}{|c|c|c|c|c|}
\hline \multirow{2}{*}{$\begin{array}{l}\text { Field Properties } \\
\text { Karakteristike područja }\end{array}$} & \multicolumn{4}{|c|}{ Sample Fields (SF) - Pokusne plohe } \\
\hline & SF 1 & SF 2 & SF 3 & SF 4 \\
\hline Aspect - Položaj & $\begin{array}{l}\text { North-east } \\
\text { Sjeveroistok }\end{array}$ & $\begin{array}{l}\text { South-east } \\
\text { Jugoistok }\end{array}$ & $\begin{array}{l}\text { South-east } \\
\text { Jugoistok }\end{array}$ & $\begin{array}{l}\text { North-east } \\
\text { Sjeveroistok }\end{array}$ \\
\hline Slope (\%) - Nagib (\%) & 18 & 9 & 9 & 18 \\
\hline Altitude $(m)$ - Visina $(m)$ & 1356 & 1400 & 1530 & 1562 \\
\hline Stand type - Vrsta sastojine & $\begin{array}{l}\text { Fir } \\
\text { Jela }\end{array}$ & $\begin{array}{l}\text { Fir-Scots pine } \\
\text { Jela-Bijeli bor }\end{array}$ & $\begin{array}{l}\text { Beech } \\
\text { Bukva }\end{array}$ & $\begin{array}{l}\text { Beech } \\
\text { Bukva }\end{array}$ \\
\hline Soil type - Vrsta tla & $\begin{array}{l}\text { Light clay } \\
\text { Laka glina }\end{array}$ & $\begin{array}{c}\text { Sandy clayey mud } \\
\text { Pjeskovita glinasta ilovača }\end{array}$ & $\begin{array}{c}\text { Sandy clayey mud } \\
\text { Pjeskovita glinasta ilovača }\end{array}$ & $\begin{array}{c}\text { Sandy clayey mud } \\
\text { Pjeskovita glinasta ilovača }\end{array}$ \\
\hline
\end{tabular}


widely preferred for log extraction. The study area has a northern aspect with an altitude ranging between 410 and $1600 \mathrm{~m}$ a.s.l. The average annual rainfall is $816.7 \mathrm{~mm} /$ year and average temperatures ranges from below 0.4 to $28.5^{\circ} \mathrm{C}$ during the summer, with an annual average of $13.01^{\circ} \mathrm{C}$.

The study area forests are managed as high forests and have mixed stands that include Fagus orientalis Lipsky, Pinus sylvestris L. and Abies nordmanniana ssp. bornmüllerina Mattf. The silvicultural method used is the clear cut system. Trees to be removed are felled, delimbed, topped, and bucked into logs motor-manually. The scheduled amount of timber extraction was $27,548.70 \mathrm{~m}^{3} /$ year for the research period. The study area covered 5274 ha of forested land and had a total of $78 \mathrm{~km}$ of forest roads. The soil type of the sample fields was generally sandy clayey mud. Four skid trails in the production compartment Nos. 84 and 85 located within the borders of the Asar Forest Management were designated as the test sites.

The study area has typically appropriate ground skidding features, with slopes ranging from 0 to $33 \%$, and the extracting activities are carried out successively using farm tractors as the suitable vehicles under these conditions (Erdaş et al., 2007).

\section{Establishment of the runoff plots - Utvrđivanje ploha otjecanja oborina}

A runoff block (sample field) was established for each of the four designated test sites. Two of the blocks had 9\% and the other two $18 \%$ sloping trails. Two of the blocks were planted with conifers and the other two with deciduous stands, with two facing north and the other two facing south (Table 1). Each block had three runoff plots. One of the runoff plots was left empty for the control (CNT), while wood chips (C) and slash (S), respectively, were deposited in the other two. The wood chips plots were laid without compacting with $20 \mathrm{~kg}\left(4 \mathrm{~kg} \mathrm{~m}^{-2}\right)$ of wood chips

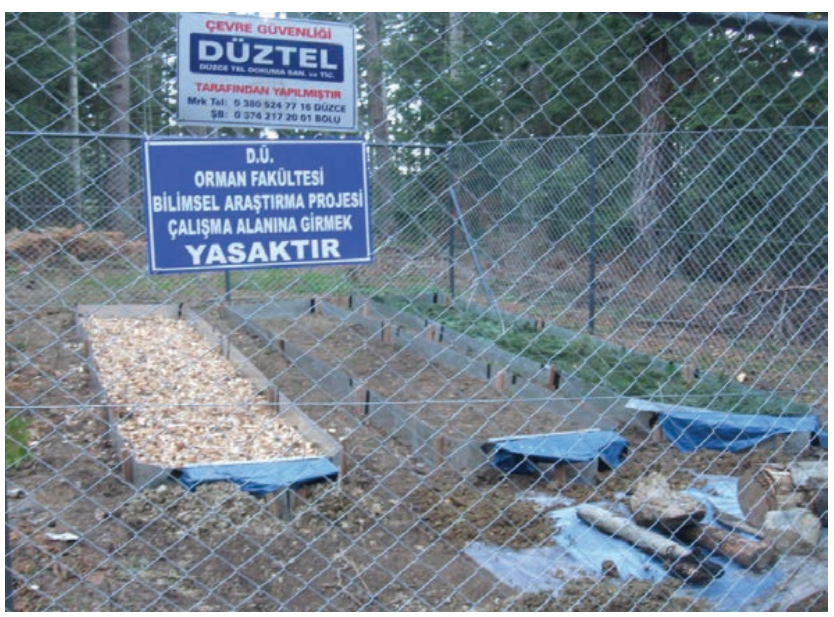

Figure 1. Establishment of runoff plots on skid trails Slika 1. Definiranje ploha otjecanja oborina na traktorskim vlakama at a thickness of exactly $1 \mathrm{~cm}$. The wood chips were obtained from a private workshop in the region of the study area. In the slash plots, branch-leaf logging residues obtained from the test area was placed so as to cover the whole of the plot $\left(1.5 \mathrm{~kg} \mathrm{~m}^{-2}\right)$. The $1 \times 5 \mathrm{~m}$ plots were established with the long sides parallel to the slope direction. The sides and upper edges of the plots were constrained by $20 \mathrm{~cm}$-wide metal sheets, with $10 \mathrm{~cm}$ of these sheets buried in the soil. The joints of the sheets were suitably connected and sealed with silicone to prevent leakage of water at the sides. An inlaid structure was formed by inserting a plastic nylon layer at the bottom edge and the runoff water was deposited in a collection tank (Fig. 1). The runoff water was measured by scale cylinders in the collection vessel and converted to $\mathrm{mm}$ units according to the plot area of $5 \mathrm{~m}^{2}$ (Zengin, 1997). In order to protect the plots, the study area was surrounded by a fence.

\section{Water sample collection and laboratory analysis - Prikupljanje uzoraka vode i laboratorijska analiza}

In determining the amount of the runoff, the amount of runoff passing into the soil after a rainfall was measured and recorded. Measurement of the runoff accumulated in the collection tank was carried out using scale cylinders. During the study, the runoff measurements were recorded repeatedly after each rain. The amount of runoff occurring after prolonged and heavy rainfall was measured on the same day or the next day. In this way the risk of exceeding the capacity of the storage tanks was prevented. When rainfall was not long term or severe, monthly measurements were taken. Nine measurements were taken from the study area throughout September 2014-March 2016. A total of 108 water samples were collected from the test sites, 36 each from the control, wood chips and slash plots. After the measurement and recording process was completed, the runoff in the storage tanks was completely drained.

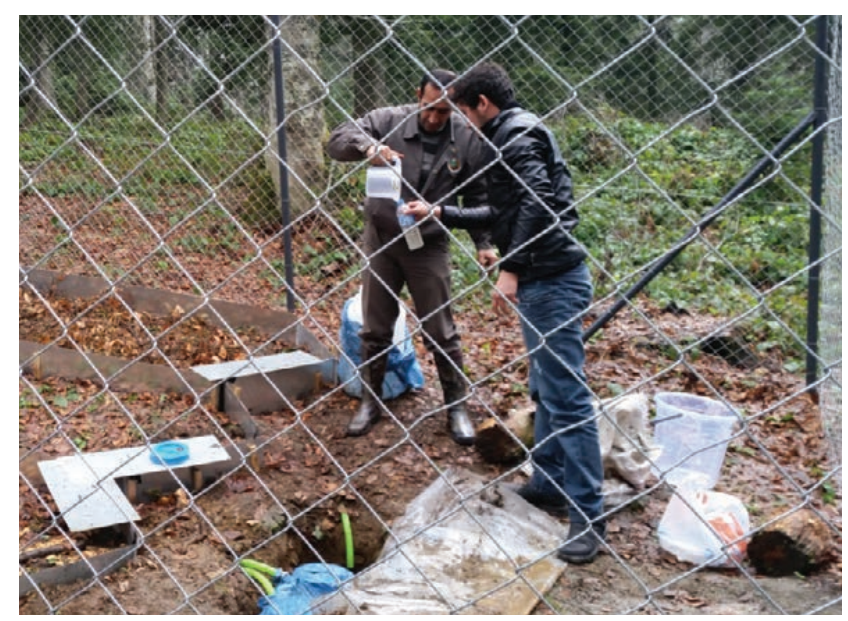

Figure 2. Water sample collection

Slika 2. Prikupljanje uzoraka vode 

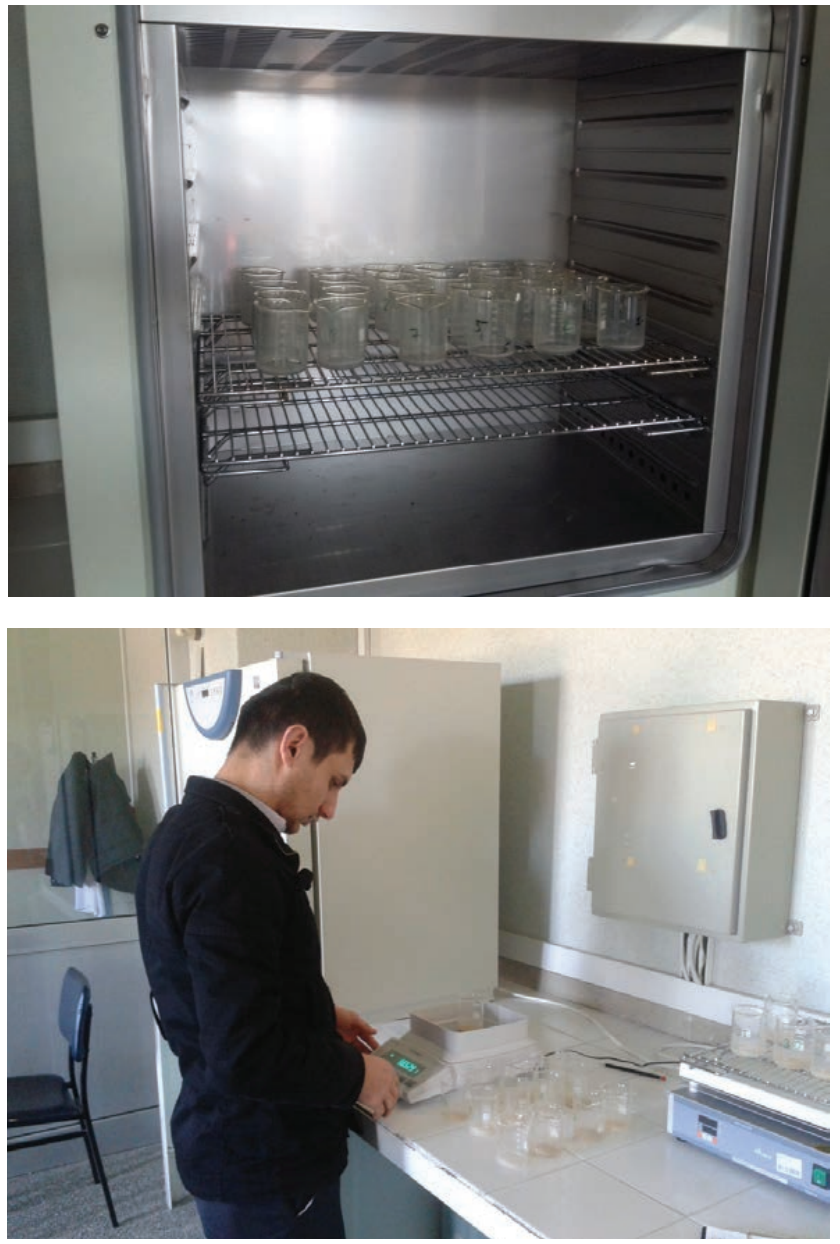

Figure 3. Water sample analysis at the Faculty of Forestry Watershed Laboratory

Slika 3. Analiza uzoraka vode u laboratoriju Watershed na Šumarskom fakultet

In order to determine the amount of suspended sediment, for each plot a $0.5 \mathrm{~L}$ sample of water taken from the runoff storage tank was brought to the laboratory and put into the heating oven (For $1-2$ days at $\left.70^{\circ} \mathrm{C}\right)$. After the runoff water was evaporated, the samples of residual suspended sediment were weighed on a precision scale. The specified value was calculated according to the total runoff amount accumulated in the storage tank and the total suspended sediment it carried (Figs. 2,3). The materials coming from the plots collecting areas were trapped in a sieve in the collection tank and were not used in determining the amount of suspended sediment (Şensoy and Kara, 2013).

\section{Density and technical specifications of the skid trails - Gustoća i tehničke specifikacije traktorskih vlaka}

An investigation was carried out of the density and technical characteristics of the skid trails in the study area where logs had been extracted using farm tractors. In order to do this, first, each skid trail was sampled at intervals of $20 \mathrm{~m}$ from the beginning to the end. Points were determined at intervals of $20 \mathrm{~m}$ using a global positioning system (GPS) device (horizontal accuracy: $<0.4 \mathrm{~m}$ RMS). These points were placed in a geographic information systems (GIS) environment and the length of each lane was determined. Thus, measurements were made on all of the skid trails and these values were recorded in a data log. In addition, the width of the skid trail was measured at each point. The density of the skid trails was then found using these data.

\section{Statistical analyses - Statistička analiza}

The Kolmogorov-Smirnov test was used to determine whether or not the data were normally distributed. As the data did not show a normal distribution, normal distributions were provided by applying the square root transformation. Variance analysis was used to detect any difference in the amounts of sediment and runoff between the plots in the experimental sites. The Independent Samples $t$-Test was applied to find differences among the plots in the factors of aspect, slope and tree type (deciduous and coniferous). All statistical analyses were performed using the SPSS 19 package program.

\section{RESULTS AND DISCUSSION REZULTATI I DISKUSIJA}

\section{Slope class findings - Utvrđivanje nagiba u području istraživanja}

Except for the north-western parts of the study area, the land is not generally sloping. The study area consists of flat

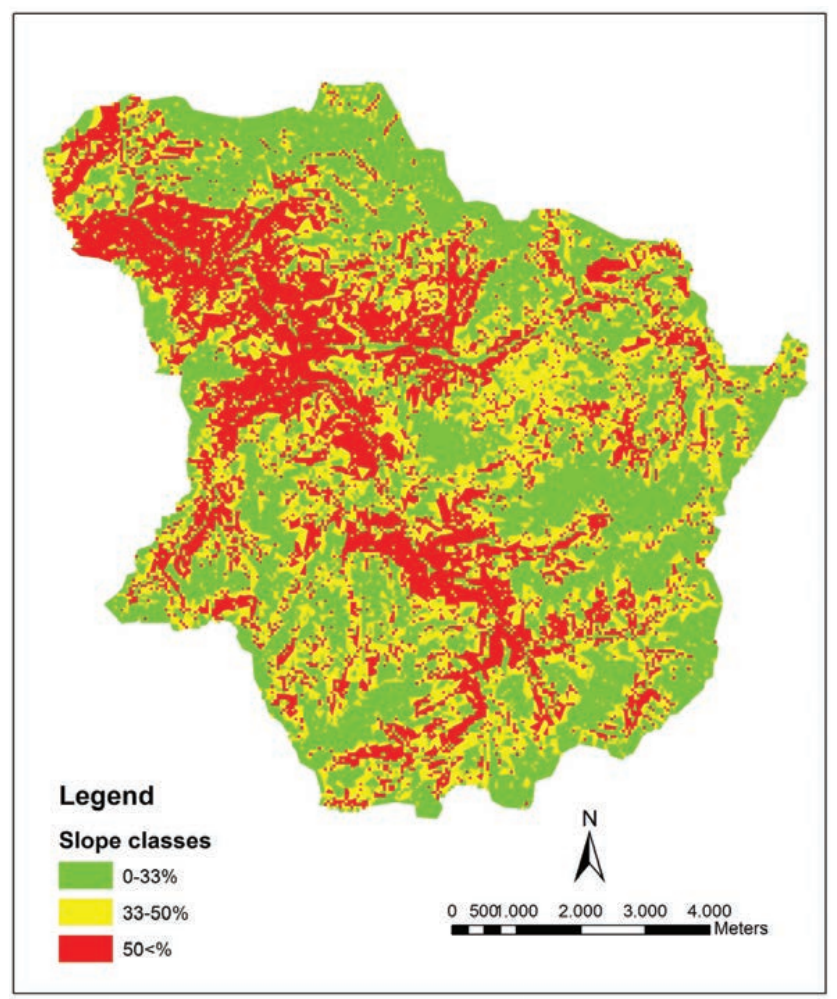

Figure 4. Map of study area slope classes

Slika 4. Karta klasa nagiba u području istraživanja 
and nearly flat land. Slope is one of the most important factors in determining the method of extraction of logs from a compartment (Bayoğlu, 1996; Garland, 1997; Erdaş et al., 2014). For this reason, a slope map of the study area is shown in Figure 4. According to this, $41.79 \%$ (3472 ha) of the total study area of 8308 ha is suitable (slope $0-33 \%$ ) for extraction work using agricultural tractors.

\section{Existing skid trail findings - Utvrdivanje postojećih traktorskih vlaka}

The skid trails of the compartments in the study area were measured to determine the extent of the area they covered. The average slope ranges of the skid trails was recorded $0-33 \%$ in the compartments. According to the findings obtained from the skid trails in compartment No. 85 , the average trail width was $2.72 \mathrm{~m}$ and the average length was $308 \mathrm{~m}$. The hectare density and coverage areas of the skid trails were found to be $108 \mathrm{~m} /$ ha and $293 \mathrm{~m}^{2}$ / ha, respectively. In addition, a total of 22 skid trails were found in the compartment, with the shortest being $120 \mathrm{~m}$ in length, while the longest was about $700 \mathrm{~m}$ long.

According to the findings, the average width of the skid trails in compartment No. 86 was $2.97 \mathrm{~m}$ and the average length was $320 \mathrm{~m}$. The densities and coverage areas of the skid trails in the compartment were determined to be $125 \mathrm{~m} /$ ha and $370 \mathrm{~m}^{2} / \mathrm{ha}$, respectively. In addition, there were a total of 23 skid trails in the compartment, with the shortest having a length of $60 \mathrm{~m}$ and the longest a length of approximately $1100 \mathrm{~m}$.

\section{Amount of runoff and suspended sediment - Količina otjecanja i suspendiranog nanosa}

Measurements during the period of September 2014-March 2016 were assessed by taking the nine plot measurements. The average runoff rates in the test site plots were $6.32 \mathrm{~mm}$ $/ \mathrm{m}^{2}$ in the control plots, $6.13 \mathrm{~mm} / \mathrm{m}^{2}$ in the wood chips plots and $6.03 \mathrm{~mm} / \mathrm{m}^{2}$ in the slash plots.

In the period covering runoff from the plots, the total sediment transported and the amounts of suspended sediment transported from the sample field plots are given in Table 2. The amount of sediment was found to be $2.58 \mathrm{~g} \mathrm{~m}^{-2}$ in the control plots, $1.61 \mathrm{~g} \mathrm{~m}^{-2}$ in the wood chips plots and 2.13 $\mathrm{g} \mathrm{m}^{-2}$ in the slash plots. An annual average of $16.61 \mathrm{~g} \mathrm{~m}^{-2}$ year $^{-1}$ of soil loss was found in the control plots. Şensoy and Kara (2013) carried out a study within the boundaries of a village and the average amount of suspended sediment transported annually from the unit on the long plot was determined as $809.68 \mathrm{~g} \mathrm{~m}^{-2}$ and $766.53 \mathrm{~g} \mathrm{~m}^{-2}$ on the short plot. These values were high because the slope was between 25 $30 \%$ and the plots were not in a closed stand.

In the study area, the hectare density and coverage areas of the skid trails were determined as $117 \mathrm{~m} / \mathrm{ha}$ and $332 \mathrm{~m}^{2}$ /

Table 2. Suspended sediment in sample fields

Tablica 2. Suspendirani nanos u uzorkovanim područjima

\begin{tabular}{|c|c|c|c|c|c|c|c|c|c|c|c|c|}
\hline \multicolumn{13}{|c|}{ Suspended Sediment - Suspendirani nanos } \\
\hline \multirow{3}{*}{$\begin{array}{c}\text { SAMPLING } \\
\text { PERIODS } \\
\text { VRIJEME } \\
\text { UZORKOVANJA }\end{array}$} & \multicolumn{12}{|c|}{ Sample Fields - Pokusne plohe } \\
\hline & \multicolumn{3}{|c|}{ SF1 } & \multicolumn{3}{|c|}{ SF2 } & \multicolumn{3}{|c|}{ SF3 } & \multicolumn{3}{|c|}{ SF4 } \\
\hline & C & CNT & S & C & CNT & S & C & CNT & S & C & CNT & S \\
\hline $\begin{array}{c}\text { September } 2014 \\
\text { Rujan } 2014 .\end{array}$ & 2.53 & 4.20 & 3.59 & 0.28 & 1.95 & 1.75 & 0.30 & 0.48 & 0.37 & 0.06 & 1.05 & 0.86 \\
\hline $\begin{array}{l}\text { December } 2014 \\
\text { Prosinac } 2014 .\end{array}$ & 0.17 & 1.37 & 1.17 & 0.64 & 1.02 & 0.92 & 0.88 & 1.15 & 0.95 & 0.20 & 0.37 & 0.22 \\
\hline $\begin{array}{c}\text { May } 2015 \\
\text { Svibanj } 2015 .\end{array}$ & 1.09 & 1.76 & 1.50 & 4.54 & 3.01 & 2.61 & 0.48 & 3.78 & 2.08 & 1.09 & 1.31 & 1.12 \\
\hline $\begin{array}{r}\text { June } 2015 \\
\text { Lipanj } 2015 .\end{array}$ & 5.12 & 2.40 & 2.24 & 0.80 & 1.66 & 1.44 & 1.39 & 2.24 & 1.51 & 1.10 & 1.76 & 1.50 \\
\hline $\begin{array}{r}\text { June } 2015 \\
\text { Lipanj } 2015 .\end{array}$ & 0.80 & 1.43 & 1.14 & 0.38 & 0.79 & 0.78 & 1.30 & 2.26 & 2.03 & 0.65 & 1.17 & 0.86 \\
\hline $\begin{array}{l}\text { August } 2015 \\
\text { Kolovoz } 2015 .\end{array}$ & 4.71 & 7.24 & 5.52 & 0.65 & 1.22 & 1.07 & 0.89 & 1.49 & 1.31 & 0.56 & 0.97 & 0.79 \\
\hline $\begin{array}{r}\text { October } 2015 \\
\text { Listopad } 2015 .\end{array}$ & 1.36 & 1.74 & 1.39 & 0.65 & 1.58 & 1.39 & 0.24 & 0.36 & 0.25 & 0.39 & 0.69 & 0.44 \\
\hline $\begin{array}{l}\text { December } 2015 \\
\text { Prosinac } 2015 .\end{array}$ & 9.13 & 14.71 & 12.81 & 1.46 & 2.16 & 1.81 & 0.80 & 3.32 & 2.98 & 0.62 & 0.98 & 0.81 \\
\hline $\begin{array}{l}\text { March } 2016 \\
\text { Ožujak } 2016 .\end{array}$ & 0.19 & 0.30 & 0.24 & 1.72 & 2.69 & 2.35 & 10.40 & 16.96 & 14.42 & 0.30 & 1.25 & 0.38 \\
\hline $\begin{array}{l}\text { Average } \\
\text { Prosjek }\end{array}$ & 2.79 & 3.90 & 3.29 & 1.23 & 1.79 & 1.57 & 1.85 & 3.56 & 2.88 & 0.55 & 1.06 & 0.78 \\
\hline
\end{tabular}


ha, respectively. Accordingly, the amount of sheet erosion that occurred on the skid trails in the compartments as a result of extraction operations was found to be $4186.52 \mathrm{~g}$ $\mathrm{ha}^{-1}$ year ${ }^{-1}$. In their study, Sidle et al. (2004) estimated the amount of sheet erosion on the skid trails as $272 \pm 20$ tons ha $^{-1}$ year $^{-1}$ as a result of the compartment extraction process. Gumus and Turk (2016) found 134009 tons / ha of land loss in the skid trails over a long-term period. The values varied according to the type of stand, the precipitation and the use of the trail. Gürtan (1975), Ylldırım (1989) and Tomasic (1996) reported that forest land could be damaged during logging extractions, especially in sloping areas. They emphasized that these losses are generally in the form of erosion-susceptible channels and forest land destruction and develop directly in proportion to loss of vegetation cover, slope, transport activity and amount of rainfall. Görcelioğlu (2004) stated that, in the planning of skid trails, factors that must be considered are that the trails lead to erosion and that the machines forming the wheel tracks in the ground cause compression and erosion in the stands. Turk and Yildız (2018) in their study used slash with wood chips to repair the loss of inorganic plant nutrients in skid trails and results showed that cations and anions were 1.11-4.5 times higher in the wood chips plots and 1.08-3.46 times higher in the slash plots than in comparable control plots. It was determined that soil erosion had been reduced and some inorganic plant nutrients had been reestablished, and thus, by spreading logging residues on it, the skid trail soil had been restored. Agherkakli et al. (2014) studied to quantify potentially mitigating effects of slash cover on soil compaction and rutting on skid trails. In the study; compared to bare soils, soil bulk density was not significantly reduced by light slash density; however, soil bulk density was significantly reduced (16\%) by heavy slash up to five machine passes on steep slopes. Besides, light and heavy slash significantly reduced rut depth (nearly double) in both slope classes (downhill $<20 \%->20 \%$ ).

\section{PLOT COMPARISON RESULTS REZULTATI USPOREDBE PLOHA}

According to the results of a total of 108 water samples taken to determine the soil loss from the plots in the test sites, the average amount of soil loss was measured as $2.58 \mathrm{~g} \mathrm{~m}^{-2}$ in the control plots, $2.13 \mathrm{~g} \mathrm{~m}^{-2}$ in the slash plots and $1.61 \mathrm{~g}$ $\mathrm{m}^{-2}$ in the wood chips plots. In other words, it was determined that the soil loss in the control plots was about 1.2 times higher than that in the slash plots and 1.6 times higher than that in the wood chips plots. In this study, in order to reduce the sheet erosion on skid trails, wood chips application was shown to be better than slash. According to the results of variance analysis on sediment amounts, a statistically significant difference was found between the suspended sediment quantities transported in the plots $(P<0.05)$. Suspended se-

Table 3. Variance analysis results for transported suspended sediment Tablica 3. Rezultati analize varijance za transportirani suspendirani nanos

\begin{tabular}{|c|c|c|c|c|c|}
\hline $\begin{array}{l}\text { Parameters } \\
\text { Parametri }\end{array}$ & $\begin{array}{l}\text { Plots } \\
\text { Plohe }\end{array}$ & $\begin{array}{c}\text { Number Of Samples } \\
\text { Broj uzoraka }\end{array}$ & $\begin{array}{l}\text { Average } \\
\text { Prosjek }\end{array}$ & $\begin{array}{l}\text { Standard Error } \\
\text { Standardn greška }\end{array}$ & $P^{*}$ \\
\hline \multirow{3}{*}{$\begin{array}{l}\text { Suspended Sediment } \\
\text { Suspendirani nanos }\end{array}$} & CNT & 36 & $1.159 \mathrm{a}$ & 0.764 & \multirow{3}{*}{0.044} \\
\hline & C & 36 & $0.991 b$ & 0.693 & \\
\hline & S & 36 & $1.097 \mathrm{ab}$ & 0.716 & \\
\hline \multirow{3}{*}{$\begin{array}{c}\text { Runoff }\left(\mathrm{mm} / \mathrm{m}^{2}\right) \\
\text { Otjecanje }\end{array}$} & CNT & 36 & $6.032 \mathrm{a}$ & 0.281 & \multirow{3}{*}{0.774} \\
\hline & C & 36 & $6.128 \mathrm{a}$ & 0.297 & \\
\hline & $S$ & 36 & 6.318 a & 0.282 & \\
\hline
\end{tabular}

${ }^{*} P<0.05$

Table 4. Results of $t$-test for other parameters in plots with transported suspended sediment

Tablica 4. Rezultati t-testa za druge parametre u plohama s transportiranim suspendiranim nanosom

\begin{tabular}{|c|c|c|c|c|c|c|c|}
\hline $\begin{array}{l}\text { Parameters } \\
\text { Parametri }\end{array}$ & $\begin{array}{l}\text { Plots } \\
\text { Plohe }\end{array}$ & $\begin{array}{c}\text { Number of } \\
\text { Samples } \\
\text { Broj uzoraka }\end{array}$ & $\begin{array}{c}\text { Difference in } \\
\text { the Averages } \\
\text { Razlika u } \\
\text { prosjecima }\end{array}$ & $\begin{array}{l}\text { Standard Error } \\
\text { Standardna } \\
\text { greška }\end{array}$ & $F$ & $\mathrm{~T}$ & $\boldsymbol{P}^{*}$ \\
\hline \multirow{3}{*}{$\begin{array}{l}\text { Aspect } \\
\text { Položaj }\end{array}$} & CNT & 36 & -0.081 & 0.258 & 0.098 & 0.316 & 0.754 \\
\hline & C & 36 & 0.008 & 0.234 & 0.490 & 0.034 & 0.973 \\
\hline & $S$ & 36 & 0.105 & 0.241 & 0.251 & 0.433 & 0.668 \\
\hline \multirow{3}{*}{$\begin{array}{l}\text { Slope } \\
\text { Nagib }\end{array}$} & CNT & 36 & 0.081 & 0.258 & 0.098 & 0.316 & 0.754 \\
\hline & C & 36 & 0.008 & 0.234 & 0.490 & 0.034 & 0.973 \\
\hline & $S$ & 36 & 0.105 & 0.241 & 0.251 & 0.433 & 0.668 \\
\hline \multirow{3}{*}{$\begin{array}{l}\text { Tree Type } \\
\text { Vrsta stabla }\end{array}$} & CNT & 36 & 0.216 & 0.256 & 0.000 & 0.846 & 0.403 \\
\hline & C & 36 & 0.320 & 0.228 & 1.852 & 1.402 & 0.170 \\
\hline & $S$ & 36 & 0.273 & 0.237 & 0.000 & 1.149 & 0.258 \\
\hline
\end{tabular}


diments transported in the control plots were the highest (1.159), while the lowest (1.097 and 0.991) were transported in the slash and wood chips plots, respectively. According to the results of variance analysis on the mean runoff rates, no statistically significant difference was found between the runoff quantities in the plots $(P>0.05)$ (Table 3$)$.

The difference between the suspended sediment quantities transported in the plots and the other variables was revealed by the $t$-test. There was no statistically significant difference among the suspended sediment quantities in the plots according to aspect (north or south), slope or tree type (deciduous or coniferous) $(P>0.05)$ (Table 4$)$.

\section{CONCLUSION ZAKLJUČAK}

This study investigated the sheet erosion that occurs on skid trails as a result of industrial log skidding using farm tractors and the use of wood chips and slash to minimize the soil loss.

As a result of this study, the average amount of runoff in the sample fields was found as $6.32 \mathrm{~mm} / \mathrm{m}^{2}$ in the control plots, $6.13 \mathrm{~mm} / \mathrm{m}^{2}$ in the wood chips plots and $6.03 \mathrm{~mm} / \mathrm{m}^{2}$ in the slash plots. The average amount of suspended sediment transported in the control plots was $2.58 \mathrm{~g} \mathrm{~m}^{-2}$, in the wood chips plots $1.61 \mathrm{~g} \mathrm{~m}^{-2}$ and in the slash plots $2.13 \mathrm{~g} \mathrm{~m}^{-2}$. In other words, it was determined that the amount of soil loss in the control plots was about 1.2 times higher than in the slash plots and 1.6 times higher than in the wood chips plots. In this study, the loss of soil carried by sheet erosion that occurs in the skid trails was reduced by using logging residues such as wood chips and slash. In this study, in order to reduce the sheet erosion on skid trails, wood chips application was shown to be better than slash.

According to the results of variance analysis on sediment amounts; a statistically significant difference was found between the suspended transported sediment quantities on the skid trails $(P<0.05)$. The transported suspended sediments were the highest (1.159) in the control plots, while the lowest (1.097 and 0.991) were transported in the slash and wood chips plots, respectively. According to the results of variance analysis of the mean runoff rates, no statistically significant difference was found between the runoff quantities in the plots $(P>0.05)$. No statistically significant difference between the suspended sediment quantities transported in the plots and the other variables of aspect (north or south), slope or tree type (deciduous or coniferous) was revealed by the $t$-test $(P>0.05)$. There was no significant relationship between the two slope groups due to the small difference. If a greater slope group is attempted in next research, a significant difference may be obtained.

Of the study area with a total size of 8308 hectares, $41.79 \%$ is suitable for extraction work with agricultural tractors. In the study area, the hectare density and coverage areas of the skid trails were determined as $117 \mathrm{~m} /$ ha and $332 \mathrm{~m}^{2} / \mathrm{ha}$, respectively. Accordingly, the amount of sheet erosion occurring on the skid trails was found to be $4186.52 \mathrm{~g} \mathrm{ha}^{-1} \mathrm{yr}^{-1}$ as a result of the extraction operations in the compartments.

With this study it has become clear that logging residues can be used to reduce the sheet erosion that occurs in the skid trails after logging extraction. Apart from the use of logging residues, the rehabilitation of the skid trails should be carried out via planting and physical interventions to overturn the trail soil and, most importantly, skid trail density should be reduced and unnecessary usage of areas should be prevented by optimizing the layout of the trails.

\section{ACKNOWLEDGMENTS} ZAHVALE

This study constitutes a part of the Master's thesis work entitled "Effects of Extracting Logs on Skid Trails on Soil Loss and Soil Nutrient Status" prepared for the Duzce University Institute of Science and Technology, Department of Forest Engineering. We are very grateful to the Duzce University Scientific Research Projects Commission Presidency and thank them for supporting this study (Project No. 2014.02.02.257)

\section{REFERENCES}

\section{LITERATURA}

- Acar, H.H, 1994: Transport Plans in Forestry and Creation of Forest Transport Plans in Mountainous Areas, Unpublished Ph.D. dissertation, Karadeniz Technical University, Institute of Science and Technology, Trabzon.

- Agherkakli, B., A. Najafi, S.H. Sadeghi, E. Zenner, 2014: Mitigating effects of slash on soil disturbance in ground-based skidding operations. Scandinavian Journal of Forest Research, 29 (5): 1-7.

- Arocena, J.M., 2000: Cations in solution from forest soils subjected to forest floor removal and compaction treatments, For. Ecol. Manag., 133: 71-80.

- Bayoğlü, S., 1996: Planning Forest Transportation, Istanbul University Publication No. 3941, I.U. Institute of Science and Technology Publication No. 8, İstanbul.

- Bayoğlu, S., 1972: A survey of Forest Transport and Development Facilities in Turkey, Istanbul University Faculty of Forestry Journal, İstanbul, 1747 (185): 73.

- Balc1, A.N., 1978: Erodibilite Characteristics of Some Forest Soils Developed Under Arid and Damp Climatic Conditions, Istanbul University Faculty of Forestry Publication No. 248, Istanbul.

- Buckley, D.S., T.R. Crow, E.A. Nauertz, K.E. Schulz, 2003: Influence of skid trails and haul roads on understory plant richness and composition in managed forest landscapes in upper Michigan, USA, For. Ecol. Manag., 175: 509-520.

- Cudzik, A., M. Brennensthul, W. Białczyk, J. Czarnecki, 2017: Damage to soil and residual trees caused by different logging 
systems applied to late thinning. Croatian Journal of Forest Engineering, 38 (1): 83-95.

- Erdas, O., H. Yllmaz, A. E. Akay, S. Gümüs, 2007: Planning Harvesting Systems by Using GIS Techniques, In: Proceedings of International Symposium Bottlenecks, Solutions. and Priorities in the Context of Functions of Forest Resource, pp.322-329, October 2007, İstanbul, Turkey.

- Erdaş, O., H.H. Acar, M. Eker, 2014: Forest Products Transport Techniques, Karadeniz Technical University, Faculty of Forestry Publication No. 233/39, Trabzon.

- Garland, J.J., 1997: Designated Skid Trails Minimize Soil Compaction, Forest Research Laboratory, School of Forestry, Oregon State University Extension Service, Corvallis, OR, USA.

- Godefroid, S., N. Koedam, 2004: The impact of forest paths upon adjacent vegetation: Effects of the path surfacing material on the species composition and soil compaction, Conserv. 119: 405-419.

- Görcelioğlu, E., 2004: Forest Roads - Erosion Relationships, Istanbul University Faculty of Forestry Publication No. 476, Istanbul.

- Gumus, S., Y. Turk, 2016: A new skid trail pattern design for farm tractors using linear programing and Geographical Information Systems, Forests, 7: 306.

- Gürtan, H., 1975: Detection of Tragic Losses in Cutting and Subdivision Removal in Mountainous and Steep Area Forests and Investigation into the Rationalization of These Operations, TÜBİTAK Publication No. 250, TOAG Series No. 38, Ankara.

- Magagnotti, N., R. Spinelli, 2011: Financial and energy cost of low-impact wood extraction in environmentally sensitive areas, Ecol. Eng., 37: 601-606.

- Makineci, E., M.Demir, E., Yilmaz, 2007: Long term harvesting effects on skid road in a Fir (Abiesbornmulleriana Mattf.) plantation forest. Build. Environ., 42: 1538-1543.

- Marshall, V.G., 2000: Impacts of forest harvesting on biological processes in northern forest soils, For. Ecol. Manag., 133: 43-60.

- Messina, M.G., S.H. Schoenholtz, M.W. Lowe, Z. Wang, D.K. Gunter, A.J. Londo, 1997: The initial responses of woody vegetation, water quality, and soils to harvest: The intensity of a
Texas bottom and hardwood ecosystem, For. Ecol. Manag., 90: 201-215.

- Ozturk T., 2016: The effects on soil compaction of timber skidding by tractor on skid roads in a plantation forest in northern Turkey, Sumarski List, 140: 485-491.

- Şensoy, H., D. Kara, 2013: Determination of surface flow and suspended sediment of two different lengths of slope using the parcel method, Artvin Coruh University Forest Faculty Journal, 14(2): 216-224.

- Sidle, R.C., S. Sasaki, M. Otsuki, S. Noguchi, A.R. Nik, 2004: Sediment pathways in a tropical forest: Effects of logging roads and skid trails. Hydrolysate. Process., 18: 703-720.

- Spinelli, R., N. Magagnotti, R. Visser, 2015: Productivity models for cable yarding in Alpine forests, Eur. J. For. Eng., 1(1): 9-14.

- Tomasic, Z., 1996: Soil erosion on several longitudinal slopes of a skid trail over a four-year period (1992-1996), In: Proceedings of The Seminar on Environmentally Sound Forest Roads and Wood Transport, pp.322-334, June 1996, Sinaia, Romania.

- Turk, Y., S. Gumus, 2015: Investigation of soil and seedling damages from occurring in extraction with farm tractors. Artvin Coruh University Forest Faculty Journal, 16 (1): 55-64.

- Turk, Y., M. Yildiz, 2018: Use of branches and branch leaves in repairing loss of plant nutrient elements in skidding trails. Düzce University Science and Technology Journal, 6 (4): 941952.

- Unver, S., H.H. Acar, 2009: A damage prediction model for quantity loss on skidded spruce logs during ground base skidding in north eastern Turkey. Croatian Journal of Forest Engineering, 30: 59-65.

- Yildirim, M., 1989: Forestry Work Information, Istanbul University Faculty of Forestry Publication No: 3555/404, Istanbul.

- Zengin, M., 1997: Comparison of Forest Ecosystems in Kocaeli Region in Terms of Hydrological Afforestation, Ministry of Forestry Poplar and Rapidly Developing Species of Forest Trees Research Institute Technical Bulletin No. 182, Ministry of Forestry Publication No. 055, Directorate Publication No. 217, İzmit.

\section{SAŽETAK}

Privlačenje oblog drva jedan je od važnih koraka u proizvodnji drvnih proizvoda. Međutim, privlačenjem oblog drva nastaje šteta različitih razmjera na tlu, preostaloj sastojini i dobivenom proizvodu. Kada se proces privlačenja vrši stalno po istom mjestu, mineralno se tlo odnosi i stvaraju se kanali podložni eroziji, što uzrokuje ozbiljne probleme tijekom jakih oborina. Ovo je istraživanje istražilo površinsku eroziju koja nastaje kao rezultat privlačenja oblog drva poljoprivrednim traktorom na traktorskim vlakama te uporabu drvne sječke i šumskih drvnih ostataka kako bi se smanjio gubitak tla. Područje istraživanja obuhvaća okrug Asar u turskoj provinciji Duzce na zapadnoj obali Crnog mora, gdje se poljoprivredni traktori puno koriste za privlačenje oblog drva. Šume područja istraživanja tretiraju se kao visoke šume i imaju mješovitu sastojinu. Područje istraživanja ima tipične prikladne karakteristike za privlačenje, s nagibima u rasponu od 0 do $33 \%$ te se aktivnosti privlačenja sukcesivno izvode poljoprivrednim traktorima kao najprikladnijem vozilu u tim uvjetima. Formirano je ukupno četiri bloka (uzorkovana područja) u četiri označene traktorske vlake u području istraživanja te su u svakom bloku definirane tri plohe otjecanja oborina. Jedna je od ploha otjecanja ostavljena praznom kao kontrolna ploha $(\mathrm{CNT})$. Druga je ploha posipana drvnom sječkom $(\mathrm{C})$, a treća ploha sa šumskim drvnim ostacima (S). Ukupno je uzeto 108 uzoraka vode s testiranih područja, 36 sa svake od navedenih ploha. Uzorci vode doneseni su u laboratorij i stavljeni u laboratorijski sušionik. Nakon 
što bi oborinska voda isparila, preostali je sediment izvagan na preciznoj vagi. Specificirana je vrijednost izračunata prema ukupnoj količini otjecanja sakupljenog u spremniku i ukupnom suspendiranom nanosu kojega je nosila. Kao rezultat određena je količina prosječnoga otjecanja u CNT u iznosu od $6,32 \mathrm{~mm} / \mathrm{m} 2$, u C u iznosu od $6,13 \mathrm{~mm} / \mathrm{m}^{2}$ i u S u iznosu od $6,03 \mathrm{~mm} / \mathrm{m}^{2}$. Prosječna količina suspendiranog nanosa prenijetog u CNT bila je 2,58 $\mathrm{g} \mathrm{m}^{-2}$, u C 1,61 $\mathrm{g} \mathrm{m}^{-2}$ i u S 2,13 $\mathrm{g} \mathrm{m}^{-2}$. Prema tomu, količina gubitka tla u kontrolnim plohama bila je 1,2 puta veća nego u plohama sa šumskim drvnim ostacima i 1,6 puta veća nego u plohama s drvnom sječkom. Rezultati analize varijance pokazuju statistički značajnu razliku između količina suspendiranoga nanosa koji se odnosi s ploha $(\mathrm{p}<0,05)$. Ova je studija pokazala da se šumski drvni ostaci mogu koristiti za smanjenje površinske erozije koja nastaje na traktorskim vlakama nakon privlačenja oblog drva.

KLJUČNE RIJEČI: traktorske vlake, privlačenje debla, površinska erozija, ostaci od sječe, rehabilitacija, Turska 